\title{
Integrating Learning Management System with Facebook Function: The Effect on Perception Towards Online Project Based Collaborative Learning
}

\author{
Sharifah Nadiyah Razali ${ }^{\# *}$, Faaizah Shahbodin ${ }^{* \$}$, Mohd Hafiez Ahmad ${ }^{\&}$, Helmi Adly Mohd Noor ${ }^{+}$ \\ ${ }^{\#}$ Kolej Komuniti Selandar, \\ Jalan Batang Melaka, 77000 Selandar, Melaka, Malaysia \\ E-mail:shnadiyah@yahoo.com
}

*Faculty of Information and Communication Technology Universiti Teknikal Malaysia Melaka, Hang Tuah Jaya, 76100 Durian Tunggal, Melaka, Malaysia

E-mail:faaizah@utem.edu.my

${ }^{\$}$ Centre of Technopreneurship Development (C-TED) Universiti Teknikal Malaysia Melaka, Hang Tuah Jaya, 76100 Durian Tunggal, Melaka, Malaysia

${ }^{\&}$ Kolej Komuniti Bukit Beruang,

23, Jalan Bukit Beruang Indah 1, Taman Bukit Beruang, 75450 Melaka, Malaysia

E-mail: hafiezamani@yahoo.com

${ }^{+}$Universiti Kuala Lumpur, Malaysian Institute of Industrial Technology,

Persiaran Sinaran Ilmu, 81750 Bandar Seri Alam, Johor Bahru, Malaysia

E-mail: helmiadly@unikl.edu.my

\begin{abstract}
This study evaluates the effect on Perception towards Online Project Based Collaborative Learning (OPBCL). OPBCL was developed by integrating Moodle forum with Facebook function and using project based learning approach. A quasi-experiment was conducted with two classes of polytechnic students for three weeks which involved 54 students. Data were obtained using Perception of Online Collaborative Learning Questionnaire (POCLQ). The study was conducted to evaluate students' perceptions toward CIDOS and OPBCL platform based on Learning Environment (LE), Learning Design (LD), Learning Interaction (LI) and Soft Skills (SS) construct. All collected data were analysed using SPSS 19.0 software. Overall, the findings revealed that perception score in OPBCL platform is higher than CIDOS platform. Evaluation based on constructs showed that except for LD construct, other constructs have shown that score in OPBCL platform is higher than CIDOS platform. OPBCL has shown to be a better online learning platform that can promote students' interaction in project based learning approach.
\end{abstract}

Keywords — online project based collaborative learning; learning management system; facebook; project based learning

\section{INTRODUCTION}

A learning management system (LMS) which is also known as Course Management System (CMS) or Virtual Learning Environment (VLE) is a software application or Web-based technology that is used to plan, implement, and assess a specific learning process [1]. Typically, an LMS provides an instructor with a way to create and deliver content, monitor student participation, and assess student performance. It integrates a range of functions for teaching and learning activities. LMS makes the interaction between learner-instructor and learner-learner more convenient. HEIs empower LMS to support a high-quality education [2], [3]. LMS can be used to provide students and educators a set of tools for improving the learning processes and managing them [4]. It also provides a platform on the web, and a lot of pedagogical activities can be performed on it [5].

Nowadays most educational institutions adopt LMS via the used of open sources such as Moodle and Sakai or commercials such as Blackboard to centralise contents, learning and assessment activities in a specific learning environment [6], [7]. LMS provides a variety of communication tools such as a forum, chat, discussion board 
and video or audio conferencing [8], [9]. Learners can use these features to facilitate their communication and collaborative work in this learning environment [10]. LMS improves the quality of teaching and learning by enabling educators to monitor [11] and evaluate [12] the students' involvement. Moreover, LMS offers opportunities for increased collaboration through the interaction function [13]. Currently, Moodle (Modular Object Oriented Dynamic Learning Environment) is the most popular LMS because it is a free open source [14]-[17]. Moodle was developed by Dougiamas (1998) based on social constructivism pedagogical philosophy [18]. Therefore, it has been widely adopted by institutions. Furthermore, Polytechnics have designed and developed their own LMS using Moodle platform called CIDOS (Curriculum Information Document Online System). Therefore, OPBCL will be developed using Moodle platform.

Even the advantages of LMS are commonly known, and it is a well-known fact that without appropriate pedagogical support, the effectiveness of online learning cannot be produced. Concerns arise among educators about the use of learning theory in online learning [5], [19], [20]. The studies have been reported that most online learnings do not incorporate any learning theory or pedagogy. Witte et. al; Kivunja; and Al-Ansari et. al [12], [21], [22] emphasised the use of appropriate learning theory in online learning to increase learning effectiveness. Furthermore, previous studies have highlighted that LMS has not been fully utilised by educators. LMS provides many types of tools [8] such as communication, productivity, assessment and course management features [23]. However, educators have been found to use only the productivity feature such uploading and sharing notes or handouts while ignoring other features ([24]. Besides, the study also reported that HEIs are still using LMS in teaching due to the course content facilities. Therefore, the frequency in the use of LMS by the HEIs is very low and has become unpopular among educators ([25].

Besides that, the drawback of LMS is that uninteresting interfaces may result in decreased students' motivation [26]. Based on students' perspectives, educators must use an attractive layout that students familiar with in order to facilitate OCL [27]. In addition, Gleadow et.al [28] report that LMS face challenges in terms of engagement and accessibility. Previous literature has discussed on the communicational features of LMS which are poorly utilised in most institutions. This is because LMS do not provide supportive environments that can support interaction and communication [16], [26]. Due to the incapability and limitations of LMS, such as networking and communications [29], lecturers sought for other applications as a replacement for the built-in discussion forum in LMS [16], [30]. Martins et. al [31] also suggest on replacing traditional LMS with Social Networking Sites.

Social Networking Sites (SNSs) are online services, platforms, or sites that focus on facilitating the building of social networks or social relations among people who, for example, share interests, activities, backgrounds, or real-life connections. SNSs are a part of Web 2.0 tools that have become the most of the crucial communication tools nowadays. There is no specific definition of Social Networking Sites [32]. However, it's the core features of are to facilitate interaction and collaboration among users. Since their introduction, SNSs such as Myspace, Facebook, and Twitter have attracted millions of users, many of whom have integrated these sites into their daily practices. SNSs provide users a platform to share information, exchange views and support interaction [33]. Moreover, SNSs supported constructivist approach in learning in order to increase students' knowledge construction and to promote interaction [34]. Zaidieh [35] was described these networks as social because it allows communication and strengthen the ties between members on the Internet.

Learning through SNSs is a trending topic nowadays, especially since many studies report that students spend more time online in SNSs [30]. Recently, SNSs were adapted by more educators to be merged with education [32], [36]. Brown [37] determined ubiquitous access, ease of use, functionality, and flexibility of social technologies as a driven factor to adapt SNSs in learning. According to Zaidieh [35], SNSs offer (i) flexibility, (ii) repeatability and (iii) convenience and accessibility. The flexibility believed to be the most attractive elements that can motivate students to learn in a social network. Flexibility expands the learning option on what, when, where and how students learn. Repeatability element offers the student the opportunity to retrieve previous information immediately or later, which is not possible in traditional learning. Furthermore, it provides easy access anytime and anywhere thus helping to increase students' satisfaction.

Various studies have been conducted to examine SNS's usages in education [26]. These studies showed that SNSs enable interaction, collaboration, resource sharing, active participation, and critical thinking in educational activities [38]-[42]. Wheeler et.al, Rifkin et.al and Zourou [43]-[45] suggested that SNSs could be used to enhance the relationship, improve motivation, offer personalized material and develop collaborative skills. According to Smith [46], SNSs are capable of promoting the development of online community and extend learning beyond the classroom. Meanwhile, studies by Barbour and Plough; Zakaria; and Ventura and Martin-Monje [42], [47], [48] argued that the incorporation of social media into blended learning course can enhance the learning experiences. Moreover, Silius et. al [49] found that SNSs could improve collaborative learning and social interaction by attracting and motivating the student to participate in the learning process.

SNSs are also able to enhance connection through ease of use and easy access [50], [51]. In addition, Hamid et.al [52] indicated that SNSs could be used to improve engagement, enhance motivation, offer personalised course material and develop collaborative skills. SNSs help introvert students who feel shy to interact actively in face-to-face activities and to voice out their opinions. The study believed that introvert students had many good ideas compare to the extrovert student. Furthermore, Ractham et. al [53] have found that SNSs could build a relationship between educators and learners; promote interaction and exchange knowledge among leaners. Other previous studies that also reported the advantages of SNSs had been summarised in Table 1. 
TABLE I

ADVANTAGES OF SOCIAL NETWORKING SITES

\begin{tabular}{|l|l|}
\hline \multicolumn{1}{|c|}{ Advantage } & \multicolumn{1}{c|}{ Author/Year } \\
\hline Motivation & $\begin{array}{l}\text { West } \text { et. al., 2009; Kabilan } \text { et. al., } \\
\text { 2010; Junco } \text { et. al., 2011, Ventura and } \\
\text { Martin-Monje, 2016 }\end{array}$ \\
\hline $\begin{array}{l}\text { Engagement / } \\
\text { Interaction / } \\
\text { relationship }\end{array}$ & $\begin{array}{l}\text { Selwyn, 2009; Hurt et. al, 2012; Welch } \\
\text { and Bonnan-White, 2012; Ataie et. al, } \\
\text { 2014 }\end{array}$ \\
\hline $\begin{array}{l}\text { Transfer of } \\
\text { knowledge }\end{array}$ & Hew, 2011 \\
\hline Quality of learning & $\begin{array}{l}\text { West } \text { et. al., 2009; Kabilan } \text { et. al., } \\
\text { 2010; Ratcham and Firpo, 2011; } \\
\text { Ventura and Martin-Monje, 2016 }\end{array}$ \\
\hline Communication & Selwyn, 2009; Madge et. al., 2009 \\
\hline Critical thinking & $\begin{array}{l}\text { Bugeja, 2006; Lampe, 2008; Maher } \\
\text { and Hoon, 2008 }\end{array}$ \\
\hline Participation & Maloney,2007 \\
\hline $\begin{array}{l}\text { Sharing / } \\
\text { collaboration }\end{array}$ & $\begin{array}{l}\text { Cerda and Planas, 2011; Hern'ndez et. } \\
\text { al, 2012; Ataie et. al, 2014 }\end{array}$ \\
\hline $\begin{array}{l}\text { Learning } \\
\text { experience }\end{array}$ & $\begin{array}{l}\text { Madge } \text { et. al., 2009; Selwyn, 2009; } \\
\text { Goodwin, Kennedy and Vetere, 2010; } \\
\text { Ray and Devi, 2015 }\end{array}$ \\
\hline Satisfaction & $\begin{array}{l}\text { Duncan and Barczyk, 2015; Ray and } \\
\text { Devi, 2015 }\end{array}$ \\
\hline Performance & Junco et. al, 2011 \\
\hline
\end{tabular}

The capability of SNSs to attract, motivate and engage students in meaningful communicative practice, content exchange and collaboration have been proven by many previous researchers [54]. SNSs has also benefited education through "supporting social learning, constructivist teaching practices, authentic instruction, student centred learning, and on-demand access to learning" [55]. Furthermore, SNSs enhanced the effectiveness of collaborative learning through the integration of motivation with learning outcomes [56]. Even though, Nguyen et. al [26] exacerbate that SNSs have been originally designed for social purposes rather than education, however, the rapid development of technology makes room for the SNSs used to support pedagogy in higher education [57]. Therefore, Bower et. al [58] emphasised that educators should consider content and pedagogical aspects when design Web 2.0 learning activities. Without proper instructional design, SNSs will not be able to produce effective learning [59].

Even though earlier evidence have indicated the effectiveness of SNSs, some argue that SNSs distract learners where students spend less time in their studies thus resulting in lower knowledge performance [60]-[64]. Conversely, Pasek et. al [65] replicated study that investigated the relationship between Facebook use and which had grade reported opposite. A similar result was reported by Wang et.al [50] study which reported that SNSs do not academically improve the learning process. Although several studies have indicated that SNS enable interaction, collaboration, resource sharing, active participation, and critical thinking in educational activities [38]-[41], but it simply cannot be successful in meeting the students' needs. It can only be used as a supplement in the teaching and learning process [29]. Earlier, previous researchers have suggested on replacing LMS with SNSs due to its potential in enhancing communications, community building, and engagement, however, a study by Buzzetto-more [55] reported opposite where student do not want SNSs to replace LMS.

Based on previous studies, there are different views on LMS and SNSs. Educators cannot simply incorporate technology into learning and need to ensure that the chosen technology can support the learning objectives [66]. Even though many researchers in the field of education have looked into the potential of adapting SNSs in their teaching and learning process [25], [67], [68], various studies have focused on the integration of conventional LMS such as Moodle with SNSs.

Embi [3] recommended integrating LMS with SNSs function due to lack of communication in LMS. This was supported by Simsek [69] where the emergence of web 2.0 tools such as SNSs and blogs, has opened a space for student-centred learning such as collaborative learning. Ali et. al [70] believed that the integration of the LMS with SNSs could improve the abilities of each technology. Moreover, Holcomb and Kruger-Ross [71] found that the integration of web tools with Web 2.0 technologies such as SNSs can enhance collaboration and social presence. Recently, Nguyen et. al [26] also suggested combining a traditional LMS with the social networking environment to enhance collaborative performance, thus promoting active learning.

This has left a gap in the body of knowledge on how SNSs can be integrated into LMS platform to facilitate Online Collaborative Learning (OCL). According to Witte et. al [12], educators need to provide an online platform that is accessible, flexible and user-friendly to facilitate collaborative learning. It is essential to choose appropriate online learning tools that can foster collaboration and communication Abrami et. al [72] and avoid distraction with non-related activities Said et. al [27]. A good platform as such can increase students' interaction thereby enhancing the soft skills of students.

Therefore, with the availability problem as stated, then the study to propose effective online learning environment that can facilitate Collaborative Learning is significant. This study proposed Online Project Based Collaborative Learning (OPBCL) by integrating LMS forum with Facebook function and using project-based learning approach. Therefore, this study aims to evaluate the effect on perception towards Online Project Based Collaborative Learning.

\section{MATERIALS AND METHODS}

\section{A. Design of Study}

This study has been divided into three phases which are (i) Analysis; (ii) Design and Development; and (iii) Implementation and Evaluation. In the analysis phase, research problems have been identified based on the analysis of previous studies that have been conducted within and outside the country. Interviews with the head of the program were carried out to view the main factor that results in graduates are unemployed. A preliminary study was conducted to obtain feedback on the use of Collaborative 
Learning, CIDOS and Social Networking Sites in the context of Malaysian Polytechnics. Then, a qualitative approach was used throughout this phase in order to determine the factors and elements of OCL. Azman [73] stated that factors and elements could be identified using two approaches, which are document review and expert verification. According to Sallabas; and Best and Khan [74], [75], the document review method is the most appropriate tool to collect information in a qualitative study. Steward [76] defines materials and resources that can be used as documents to carry out the analysis and interpretation of which are (i) journals and books, (ii) research literature, and (iii) reports from scholarly research papers and materials. Analysis of theory and model related to Online Collaborative Learning (OCL) was determined through document analysis. All factors and elements that were determined from document analysis were then validated by experts to make sure that meets the objectives of the study [77], [78]. At the end of this phases, an OCL model was proposed [79].

In the design and development phase, OPBCL was designed and developed based on the proposed model [80]. In order to achieve the research goal, the prototype will be designed and developed using the ADDIE development model that consists of five phases; analysis phase, design phase, development phase, implementation phase and evaluation phase ([81], [82]. Need analysis was conducted to determine SNSs and CL based on lecturer and student preferences by distributing two set of questionnaire. Based on findings in the need analysis phase, Online Project Based Collaborative Learning was designed and develop by integrating Moodle with Facebook function and using project-based learning approach. In the implementation phase, OPBCL was set up properly, and training was given to ensure it can be used in the pilot test. Finally, in the evaluation phase, OPBCL was validated by experts and a pilot test was conducted to ensure that OPBCL functionality and readiness for the real test. Besides the OPBCL, Perception of Online Collaborative Learning Questionnaire (POCLQ) was developed to assess the effectiveness of the developed prototype. POCLQ was verified by experts, and a pilot test was conducted to ensure all instruments are reliable and valid for the real test. In the implementation and evaluation phase, a pilot study was conducted in order to ensure instruments are valid and reliable.

In implementation and evaluation phase, a procedure in the form of training and guiding the facilitators and the learners had to be developed. The facilitators' training should cover the course curriculum, learning outcomes, a method of delivery and testing procedures. Preparation of the learners includes training them on new tools (software or hardware) and student's registration. Training was given to both the treatment groups for two weeks (W12 and W13) to avoid differences in the ability to use the system. Detailed procedures for the training will be discussed in the procedure section.

\section{B. Instrument}

The instrument was developed based on the OCL construct of (i) learning environment, (ii) learning design, (iii) learning interaction and (iv) soft skills. The development of items was adapted and modified from [83]-
[87]. The items also have been agreed upon by experts based on literature through the theories related to construction and dimensional constructs. This instrument is divided into two sections:

1) Section A: Section A is related to the background of the respondents. This section contains nine items related to gender, age, residence, computer literacy, CIDOS experience, CIDOS forum experience, SNSs experience, Facebook account and PBL experience.

2) Section B: Section B consists of items that are designed to assess student's perception toward the proposed prototype. The section contains 37 items developed based on factors and elements that have been identified before in [77]. Table 2 shows the content of the questionnaire and the number of items included in this section.

TABLE II

Questionnaire CONTENT AND NuMBER OF ITEMS IN SECTION B

\begin{tabular}{|l|l|l|c|}
\hline Factor & Element & No of Item & Total \\
\hline \multirow{4}{*}{$\begin{array}{l}\text { Learning } \\
\text { Environment }\end{array}$} & Usability & LE1-LE6 & 6 \\
\cline { 2 - 4 } & Accessibility & LE7-LE9 & 3 \\
\cline { 2 - 4 } & Stability & LE10-LE12 & 3 \\
\cline { 2 - 4 } & Overall & LE13-LE14 & 2 \\
\hline \multirow{4}{*}{$\begin{array}{l}\text { Dearning } \\
\text { Design }\end{array}$} & Content & LD1-LD3 & 3 \\
\cline { 2 - 4 } & Time & LD4-LD5 & 1 \\
\cline { 2 - 4 } & Process & LD6-LD8 & 3 \\
\cline { 2 - 4 } Interaction & Evaluation & LD9-LD11 & 3 \\
\cline { 2 - 4 } & Overall & LD12 & 1 \\
\hline \multirow{4}{*}{\begin{tabular}{l} 
Soft Skills \\
\cline { 2 - 4 }
\end{tabular}} & Learner-learner & LI1-LI3 & 3 \\
\hline & $\begin{array}{l}\text { Overall } \\
\text { and Problem- }\end{array}$ & LI4-LI6 & 3 \\
\cline { 2 - 4 } & Solving & LI7 & 1 \\
\cline { 2 - 4 } & Collaboration & SS1 & 1 \\
\cline { 2 - 4 } & Communication & SS3 & 1 \\
\cline { 2 - 4 } & Overall & SS4 & 1 \\
\hline
\end{tabular}

The respondents answered the questionnaire using a Likert scale. According to Likert in 1974, the rate or level of agreement on a question can be obtained using a Likert scale. This study used a 6 Likert scale to avoid students from choosing a midpoint answer in 5 Likert scale. According to Chomeya [25], using a 6 Likert scale can reduce the deviation of personal decision making. Furthermore, a 6 Likert scale was chosen when the respondents were needed to answer either the positive or negative perception. A 5 Likert scale is not suitable for use in this study because the respondents had prior experience using the developed prototype. A 5 Likert scale is used only if there is concern that the respondents are not familiar with the environment being studied. The scale used was (1) strongly disagree, (2) disagree, (3) somewhat disagree, (4) somewhat agree, (5) agree and (6) strongly agree as illustrated in Table 3. 
TABLE III

LEVEL OF AGREEMENT SCORE

\begin{tabular}{|c|c|c|c|c|c|c|}
\hline Score & $\mathbf{1}$ & $\mathbf{2}$ & $\mathbf{3}$ & $\mathbf{4}$ & $\mathbf{5}$ & $\mathbf{6}$ \\
\hline $\begin{array}{c}\text { Level of } \\
\text { Agreement }\end{array}$ & $\begin{array}{c}\text { Strongly } \\
\text { Disagree }\end{array}$ & Disagree & $\begin{array}{c}\text { Somewhat } \\
\text { Disagree }\end{array}$ & $\begin{array}{c}\text { Somewhat } \\
\text { Agree }\end{array}$ & Agree & $\begin{array}{c}\text { Strongly } \\
\text { Agree }\end{array}$ \\
\hline
\end{tabular}

Rasch model approach was implemented to check the reliability and validity of the instruments used. In recent years, Rasch models also referred as item-response theory (IRT) or latent trait models, have provided an alternative framework for understanding measurement and alternative strategies for judging the quality of a measuring instrument [88], [89]. Applications of Rasch model can produce an instrument that is reliable and valid [90].The test was performed by 32 respondents from Politeknik Ibrahim Sultan at the user's site. Data obtained was analysed using WINSTEP version 3.68 software.

The finding showed that POCLQ instruments had high reliability with five categories of difficulties items. So, it can be concluded that POCLQ instrument is reliable and strongly accepted. The findings on items polarity also indicated that the instrument could measure any item to be measured, and its move parallel with other items that measure the construct. However, based on the analysis of item fit, six items were found to be out of 0.6-1.4 range. Moreover, from the analysis on standard residual correlations, five items were found to be overlapping. However, all the items that needed to be dropped based on the analysis of result had been refined and retained for the purpose of the study and based on expert's view.

\section{Respondents}

In this study, sample selection could not be done randomly because it could interfere with the students' schedules. The respondents are students who were takers of the Nutrition subject in the December 2014 session from Polytechnic Merlimau Melaka. A total of 54 students were involved in this study. It involves the use of intact groups of subjects in an experiment rather than assigning subjects at random to experimental treatments [91], [92]. There were two classes namely control (21 students) and treatment (33 students) class. Students involved in this study may be different in some aspects. These differences may affect the behaviour during the treatment given. In subject selection, any pre-existing differences between the experimental and control groups (which may have resulted from a non-random sampling procedure) must be identified; otherwise, differences between them can affect the research findings [93]. Therefore, a pre-test was conducted to control the preexisting differences between the intact groups.

\section{Procedure}

All respondents completed a pre-test before the intervention at the same time. Training was given to both the treatment groups for two weeks (W12 and W13) to avoid differences in the ability to use the system. The duration of the intervention lasted for 3 weeks (W14 - W16) based on lecturer lesson plan and program syllabus. Each group received an equivalent amount of instructional time. For the control group, students started do the project through CIDOS platform; meanwhile, treatment group started their project through OPBCL platform.

\section{RESULTS AND DISCUSSION}

The effect on perception towards Online Project Based Collaborative Learning was obtained using Perception of Online Collaborative Learning Questionnaire (POCLQ). The data obtained from POCLQ were analysed inferentially by including the Learning Environment (LE), Learning Design (LD), Learning Interaction (LI) and Soft Skills (SS) construct. Accordingly, when comparing students' perception between Control and Treatment groups, it was decided that the Mann Whitney Test is used. Table 4 shows that a significant difference exists among students' perception towards the platform they used between Control and Treatment group $[U=96.00, z=-4.45, p<.05]$. Based on this information, it is revealed that the Treatment group which participated using OPBCL platform (Mean Rank= 35.09) had a higher perception score than Control group which participated using CIDOS platform (Mean Rank = 15.57).

TABLE IV

PERCEPTION COMPARISON BETWEEN CONTROL AND TREATMENT

\begin{tabular}{|l|c|c|c|c|c|}
\hline Class & N & $\begin{array}{c}\text { Mean } \\
\text { Rank }\end{array}$ & $\begin{array}{c}\text { Mann- } \\
\text { Whitney } \\
\text { U }\end{array}$ & Z & $\begin{array}{c}\text { Asymp. Sig. } \\
\text { (2-tailed) }\end{array}$ \\
\cline { 1 - 3 } Control & 21 & 15.57 & 96.00 & -4.45 & .00 \\
\cline { 1 - 3 } Treatment & 33 & 35.09 & & & \\
\cline { 1 - 3 } Total & 54 & & & & \\
\hline
\end{tabular}

In addition, analysing each construct in the students' perception questionnaire based on construct of each group might be beneficial in determining the effects in terms of the performed activities. Table 5 shows that significant difference exists in the Learning Environment $(U=224.50, z$ $=-2.41, p<.05)$, Learning Interaction $(U=217.00, z=-2.44$, $p<.05)$ and soft skills $(U=169.00, z=-3.36, p<.05)$ construct between Control and Treatment group. Meanwhile, no significant difference exists in the Learning Design $(U=$ 273.00, $z=-1.60, p>.05)$ construct between Control and Treatment group.

Based on this information, it has been revealed that the perception towards Learning Environment constructed from Treatment group which participated using OPBCL platform (Mean Rank $=31.20)$ had a higher mean rank than Control group which participated using CIDOS platform (Mean Rank $=21.69$ ). In learning interaction construct, it has been indicated that the perception of Treatment group which participated using OPBCL platform (Mean Rank = 31.42) is higher than Control group which participated using CIDOS platform (Mean Rank $=21.30$ ). The result also showed that the perception of Treatment group which participated using 
OPBCL platform (Mean Rank = 32.88) is higher than Control group which participated using CIDOS platform (Mean Rank $=19.05)$ based on soft skills construct. Therefore, it can be concluded that except for Learning
Design construct, other constructs have shown a different perception between Control and Treatment groups where Treatment obtained higher scores in comparison to Control.

TABLE V

PERCEPTION COMPARISON BETWEEN CONTROL AND TREATMENT BASED ON CONSTRUCTS

\begin{tabular}{|c|c|c|c|c|c|c|}
\hline Construct & Class & $\mathbf{N}$ & $\begin{array}{l}\text { Mean } \\
\text { Rank }\end{array}$ & $\begin{array}{c}\text { Mann- } \\
\text { Whitney U }\end{array}$ & $\mathbf{Z}$ & $\begin{array}{l}\text { Asymp. Sig. } \\
\text { (2-tailed) }\end{array}$ \\
\hline \multirow{2}{*}{$\begin{array}{l}\text { Learning } \\
\text { Environment }\end{array}$} & Control & 21 & 21.69 & \multirow[t]{2}{*}{224.50} & \multirow[t]{2}{*}{-2.41} & \multirow[t]{2}{*}{.02} \\
\hline & Treatment & 33 & 31.20 & & & \\
\hline \multirow[t]{2}{*}{ Learning Design } & Control & 21 & 24.00 & \multirow[t]{2}{*}{273.00} & \multirow[t]{2}{*}{-1.60} & \multirow[t]{2}{*}{.11} \\
\hline & Treatment & 33 & 29.73 & & & \\
\hline \multirow{2}{*}{$\begin{array}{l}\text { Learning } \\
\text { Interaction }\end{array}$} & Control & 21 & 21.30 & \multirow[t]{2}{*}{217.00} & \multirow[t]{2}{*}{-2.44} & \multirow[t]{2}{*}{.02} \\
\hline & Treatment & 33 & 31.42 & & & \\
\hline \multirow[t]{2}{*}{ Soft skills } & Control & 21 & 19.05 & \multirow[t]{2}{*}{169.00} & \multirow[t]{2}{*}{-3.36} & \multirow[t]{2}{*}{.00} \\
\hline & Treatment & 33 & 32.88 & & & \\
\hline
\end{tabular}

The study was conducted to evaluate students' perceptions toward CIDOS and OPBCL platform based on Learning Environment (LE), Learning Design (LD), Learning Interaction (LI) and Soft Skills (SS) construct. Accordingly, when comparing students' perception between Control and Treatment groups, it was decided that the Mann Whitney Test is used. Overall, the findings revealed that perception score in Treatment group is higher than Control group. It shows that OPBCL had provided a better online platform compared to CIDOS. In addition, analysing each construct in the students' perception questionnaire based on the construct of each group might be beneficial in determining the effect in terms of the performed activities.

The findings clearly showed that there is a significant difference in the Learning Environment (LE), Learning Interaction (LI) and Soft Skills (SS) construct which the Treatment portrayed better perception of the OPBCL platform than CIDOS platform. Meanwhile, there is no significant difference in the Learning Design (LD) construct. This is caused by both groups who use the same learning design. The learning design in both groups has been standardized in terms of content, time, process and evaluation. Both groups agreed the learning design encourage them to participate actively in group work project. According to Ngusa (2014) [94], the learning activities must be properly designed so that learning can be effective. Proper learning design can bring success than failure [95].

In learning environment construct, it was clearly shown that the students' perception in Treatment group was higher that Control. It is also evident that OPBCL platform is better in terms of usability, stability, and accessibility. The learning environment provided by OPBCL encourages students to participate actively in group work. The supportive learning environment can encourage student participations [96]. This finding supports the findings of research question 6 where the total number of postings in OPBCL platform is higher than CIDOS platform. This proves that OPBCL can provide a better online learning environment. The active participation of students can directly enhance the soft skills of students.

As for learning interaction construct, the same results were evident whereby the perception of Treatment group was higher than Control. It confirms that OPBCL platform provided better learning interaction in terms of learnerlearner interaction and learner-instructor interaction. The better learning environment can provide better learning interaction. [96], [97] believed that supportive learning environments could encourage student's participation and increase their interaction. The finding proves that OPBCL provides a better learning environment that can encourage the student to actively participate in group work, thus increase student's interaction. With that, it can enhance students' soft skills.

Soft skills construct also reflects that the perception of Treatment group is higher than Control group. The students in Treatment group believed that OPBCL provides an effective learning platform that can enhance their critical thinking and problem-solving skills, collaboration skills, and communication skills. Hence, this study emphasises the use of OPBCL platform to enhance students' soft skills.

\section{CONCLUSIONS}

This study attempted to evaluate the effect on perception towards Online Project Based Collaborative Learning. The difference in the perception scores between Control and Treatment groups is caused by the integration of SNSs function, meaning Facebook in OPBCL platform which facilitated OCL. These findings are also consistent with the studies by Hern'dez et. al; and Ozmen and Atici [30], [98] who have stated that the current LMS is insufficient to support social interaction, resulting in low student participation when using the LMS platform. Hewit [99] believed that the way a forum is facilitated would affect the students' active participation. Therefore, previous studies have recommended that current LMS are integrated with SNSs function [3], [100]-[104]. The integration of LMS with Facebook function in OPBCL platform provides a better learning environment in terms of usability, stability, and accessibility. OPBCL has proven to be a better learning platform that can promote students' interaction in terms of easy access and instant notification. The educator can use OPBCL platform to monitor and evaluate students' contribution in CL process. The evaluation process can also promote students' interaction.

Apparently, there are constraints and drawbacks in every technology, and thus, online learning is no exception. This 
study has certain limitations that should be considered for further research. The study was conducted using only a relatively small sample, it is suggested that further research is undertaken for a larger sample, and therefore findings can be generalized. Therefore, it is suggested that further research is undertaken for a larger sample, and therefore findings can be generalized. However, this study does not intend to generalize these results to a wider population. Besides, the study was conducted quantitatively on students' perception towards OPBCL. It is recommended that a qualitative study should be done to obtain more precise information. Finally, this study was conducted by integrating Learning Management System with Facebook function. Therefore, a similar study should be conducted by integrating Learning Management System with other Social Networking Sites such WhatsApp but the selection must be based on respondent preferences.

\section{ACKNOWLEDGMENT}

Sharifah Nadiyah Razali would like to acknowledge the financial support of Universiti Teknikal Malaysia Melaka (UTeM) and the Ministry of Higher Education of Malaysia for her Ph.D. study.

\section{REFERENCES}

[1] A. P. Lopes, "Teaching With Moodle in Higher Education," in 5th International Technology, Education and Development Conference (INTED2011), 2011, pp. 970-976.

[2] R. A. Ellis and R. A. Calvo, "Minimum indicators to assure quality of LMS-supported blended learning," Educ. Technol. Soc., vol. 10, pp. $60-70,2007$.

[3] M. A. Embi, "e-learning in Malaysian Higher Education: Status, Trends and Challeges," Department of Higher Education Ministry of Higher Education 2011, 2011

[4] García-Peñalvo, F. J., M. Á. Conde, M. Alier, and M. J. Casany, "Opening learning management systems to personal learning environments," J. Univers. Comput. Sci., vol. 17, no. 9, pp. 12221240,2011

[5] A. Norazlina, "Kesan Penyesuaian Pembelajaran Berdasarkan Gaya Pembelajaran Terhadap Pembentukan Pengetahuan Pelajar," Universiti Teknologi Malaysia, 2014.

[6] A.-H. Carlos, B.-L. Miguel L., G.-S. Eduardo, A.-P. Juan I., E.-G. Guillermo, and R.-C. Adolfo, "Enhancing Learning Environments by Integrating External Applications," Bull. IEEE Tech. Comm. Learn. Technol., vol. 15, no. 1, pp. 21-24, 2013.

[7] H. Coates, R. James, and G. Baldwin, "A critical examination of the effects of learning management systems on university teaching and learning," Tert. Educ. Manag. 11(1)19-36, 2005., vol. 11, no. 1, pp. 19-36, 2005.

[8] R. Queirós, J. P. Leal, and J. Paiva, "Integrating Rich Learning Applications in LMS," State-of-the-Art Futur. Dir. Smart Learn., pp. 381-386, 2015.

[9] K. Kuosa, D. Distante, A. Tervakari, L. Cerulo, A. Fernandez, J. Koro, and M. Kailanto, "Interactive Visualization Tools to Improve Learning and Teaching in Online Learning Environments," Int. J. Distance Educ. Technol., vol. 14, no. 1, 2016.

[10] A. I. Ilyas, "Interactive Tutoring in Blended Studies: Hindrances and Solutions," Int. J. Appl. Linguist. English Lit., vol. 5, no. 1, pp. 2-3, 2016.

[11] C. Beer, K. Clark, and D. Jones, "Indicators of engagement," Proc. ASCILITE 2010, pp. 75-86, 2010.

[12] S. Witte, J. Graham, E. Grysko, S. Bistrican, and A. Piotrowski, "Every Voice Counts: Partnering Literature and LiveScribe," 2013.

[13] E. Strømman, "Participant activity and facilitator strategies in an LMS-based discussion forum," Nord. J. Digit. Lit., vol. 10, no. 12015, pp. 43-62, 2015.

[14] C.-T. Tsai, H.-T. Lin, M.-H. Hung, C.-F. Lin, and S.-M. Yuan, "Exchanging Course Content Mechanism for Moodle LMS," in 2010
International Conference on Cyber-Enabled Distributed Computing and Knowledge Discovery, 2010, pp. 464-467.

[15] F. J. Díaz, M. A. Schiavoni, M. A. Osorio, A. P. Amadeo, and M. E. Charnelli, "Integrating a learning management system with a student assignments digital repository: a case study," Int. J. Contin. Eng. Educ. Life Long Learn., vol. 25, no. 2, pp. 138-150, 2015.

[16] A. H. A. Abdallah, "E-Learning Management System from The Perspective of The Social Requirements," Zarqa University, 2016.

[17] capterra.com, "Top LMS Software," 2012. [Online]. Available: http://www.capterra.com/learning-management-systemsoftware/\#infographic.

[18] S. Kim, J. Youn, and Y. Kim, "Design of Expanded Assessment Management System for Open-Source Moodle LMS Module," in 3rd International Conference on e-Education, e-Business, e-Management and e-Learning (IPEDR), 2012, vol. 27, pp. 43-47.

[19] H. Fung and A. Yuen, 'Factors Affecting Students' and Teachers' Use of LMS - Towards a Holistic Framework," in Hybrid Learning, vol. 74411, 2012, pp. 306-316.

[20] B. M. A. D. Mastura, "A Framework on Collaborative Learning Activities to Actively Engage Students in Learning Management System," Universiti Teknikal Malaysia Melaka, 2016.

[21] C. Kivunja, "Exploring the Pedagogical Meaning and Implications of the 4Cs 'Super Skills' for the 21 st Century through Bruner's 5E Lenses of Knowledge Construction to Improve Pedagogies of the New Learning Paradigm," Creat. Educ., vol. 6, no. February, pp. 224-239, 2015.

[22] A. Al-Ansari, F. Al-Harbi, W. AbdelAziz, M. AbdelSalam, M. M. El Tantawi, and I. ElRefae, "Factors affecting student participation in extra-curricular activities: A comparison between two Middle Eastern dental schools," Saudi Dent. J., vol. 28, no. 1, pp. 36-43, 2016.

[23] S. Kumar, A. K. Gankotiya, and K. Dutta, "A comparative study of moodle with other e-learning systems," in 2011 IEEE 3rd International Conference on Electronics Computer Technology, 2011, pp. 414-418.

[24] H. Afendi, E. Mohamed Amin, and S. Abdul Halim, "Learning Management Systems in Malaysian Higher Education Institutions," 2011.

[25] D.-Z. Marijana, B. L. Aleksandra, and R. M. Aleksandar, "Fostering engineering e-learning courses with social network services," in 19th IEEE Telecommunications Forum (TELFOR), 2011, pp. 122-125.

[26] H. N. Nguyen, H. Kim, Y. Jo, and K. Dieter, "Sharing Cognition LMS : An Alternative Teaching and Learning Environment for Enhancing Collaborative Performance," Educ. Technol. Int., vol. 16, no. 1, pp. 1-30, 2015.

[27] M. Said, M. Forret, and C. Eames, "Analysis of Contradictions in Online Collaborative Learning using Activity Theory as Analytical Framework," J. Teknol., vol. 2, pp. 57-63, 2014.

[28] R. Gleadow, B. Macfarlan, and M. Honeydew, "Design for learning - a case study of blended learning in a science unit," F1000Research, vol. 4:898, 2015.

[29] S. A. Ishan and C. Y. Tham, "Implementation of Facebook Study Groups as Supplements for Learning Management Systems ( LMS ) in Adult ODL Environments," Asian Assoc. Open Univ. Journal, vol. 7, no. 1, pp. 1-11, 2011.

[30] R. Hern'ndez, H. R. Amado-Salvatierra, C. Guetl, and M. Smadi, "Facebook for CSCL, Latin-American Experience for Professors," in 2012 IEEE 12th International Conference on Advanced Learning Technologies, 2012, pp. 327-328.

[31] J. Martins, R. Gonçalves, V. Santos, and J. Pereira, "Network Based Model For E-Learning 2.0," Procedia - Soc. Behav. Sci., vol. 47, no. 0, pp. 1242-1248, 2012.

[32] Z. Du, X. Fu, C. Zhao, Q. Liu, and T. Liu, "Interactive and Collaborative E-Learning Platform with Integrated Social Software and Learning Management System," in International Conference on Information Technology and Software Engineering, 2013, vol. 212, pp. 11-19.

[33] F. Ataie, A. Shah, and M. N. Mior Nazir, "Innovative web 2.0 based collaborative learning and study circle model," in The 5th International Conference on Information and Communication Technology for The Muslim World (ICT4M), 2014, pp. 1-6.

[34] Schroeder, A., S. Minocha, and C. Schneider, "Social Software in Higher Education: The Diversity of Applications and Their Contributions to Students' Learning Experiences," Commun. Assoc. Inf. Syst., vol. 25, no. 1, pp. 547-564, 2010. 
[35] A. J. Y. Zaidieh, "The Use of Social Networking in Education: Challenges and Opportunities," World Comput. Sci. Inf. Technol. J., vol. 2, no. 1, pp. 18-21, 2012.

[36] M. H. Zakaria, J. Watson, and S. L. Edwards, "Investigating the use of Web 2.0 technology by Malaysian students," Multicult. Educ. Technol. J., vol. 4, no. 1, pp. 17-29, 2010.

[37] S. Brown, "From VLEs to Learning Webs : The Implications of Web 2 . 0 for Learning and Teaching," Interact. Learn. Environ., vol. 18, no. $1,2010$.

[38] Y. Chen, "Learning styles and adopting Facebook technology," in Technology Management in the Energy Smart World (PICMET), 2011, pp. 1-9.

[39] R. Ajjan, H., Hartshorne, Investigating faculty decisions to adopt Web 2.0 technologies: theory and empirical tests. 2008.

[40] N. Selwyn, "“ Screw Blackboard ... do it on Facebook!': an investigation of students ' educational use of Facebook," in Poke 1.0 - Facebook social research symposium', 2007, no. November, pp. 123.

[41] R. Mason, "Learning technologies for adult continuing education," Stud. Contin. Educ., vol. 28, no. 2, pp. 121-133, Jul. 2006.

[42] P. Ventura and E. Martin-Monje, "Learning specialised vocabulary through Facebook in a massive open online course," in New perspectives on teaching and working with languages in the digital era, A. Parej-Lora, C. Calle-Martinez, and P. Rodriguez-Arancon, Eds. Research-publishing.net, 2016, pp. 117-128.

[43] W. Rifkin, N. Longnecker, J. Leach, L. Davis, and L. Ortia, "Motivate students by having them publish in new media: An invitation to science lecturers to share and tes," in Motivating Science Undergraduates: Ideas and Interventions, UniServe Science Proceedings, 2009.

[44] S. Wheeler, P. Yeomans, and D. Wheeler, "The good, the bad and the wiki: Evaluating student-generated content for collaborative learning,” Br. J. Educ. Technol., vol. 39, no. 6, pp. 987-995, 2008.

[45] K. Zourou, "On the attractiveness of social media for language learning: a look at the state of the art," OpenEdition, vol. 15 , no. 1, 2012.

[46] B. V. N. Smith, "Use of online educational social networking in a school environment," North Carolina State University, Raleigh, NC, 2009

[47] M. Barbour and C. Plough, "Social networking in cybershcooling: Helping to make online learning less isolating.," TechTrends, vol. 53, no. 4, pp. 56-60, 2009.

[48] M. H. Zakaria, "E-Learning 2 . 0 Experiences Within Higher Education : Theorising Students ' and Teachers 'Experiences in Web 2.0 learning," Quensland University of Technology, 2013.

[49] K. Silius, T. Miilumäki, J. Huhtamäki, T. Tebest, J. Meriläinen, and S. Pohjolainen, "Students ' Motivations for Social Media Enhanced Studying and Learning," Knowl. Manag. E-Learning An Int. J., vol. 2, pp. 51-67, 2010.

[50] Q. Wang, W. Chen, and Y. Liang, "The Effects of Social Media on College Students," MBA Student Scholarsh., p. Paper 5, 2011.

[51] L. Dolphy, "Techniques and Tools: Effectiveness of Research-based Pedagogical Techniques through Online Learning Tools with Secondary Students," University of Northwestern, 2015.

[52] S. Hamid, J. Waycott, S. Chang, and S. Kurnia, "Appropriating Online Social Networking (OSN) Activities for Higher Education: Two Malaysian Cases," in ASCILITE, 2011, pp. 526-538.

[53] P. Ractham, L. Kaewkitipong, and D. Firpo, "The Use of Facebook in an Introductory MIS Course: Social Constructivist Learning Environment,” Decis. Sci. J. Innov. Educ., vol. 10, no. 2, pp. 165$188,2012$.

[54] N. Mills, "Situated Learning through Social Networking Communities: The Development of Joint Enterprise, Mutual Engagement, and a Shared Repertoire," CALICO J., vol. 28, no. 2, 2011.

[55] N. A. Buzzetto-more, "Social Networking in Undergraduate Education,” Interdiscip. J. Information, Knowledge, Manag., vol. 7, pp. 63-90, 2012.

[56] B. Ray and A. Devi, "Academic Debate on Using Social Networking Media: Teachers ' and Students 'Perceptions from Two Tertiary Institutions," Int. J. Learn. Teach., vol. 1, no. 2, pp. 168-173, 2015.

[57] A. Hemmi, S. Bayne, and R. Land, "The appropriation and repurposing of social technologies in higher education," J. Comput. Assist. Learn., vol. 25, no. 1, pp. 19-30, 2009.

[58] M. Bower, J. G. Hedberg, and A. Kuswara, "A framework for Web 2.0 learning design," EMI. Educ. Media Int., vol. 47, no. 3, pp. 177$198,2010$.
[59] D. G. Duncan and C. C. Barczyk, "The Facebook Effect in University Classrooms: A Study of Attitudes and Sense of Community Using an Independent Measures Control Group Design," Am. J. Manag., vol. 15, no. 3, pp. 11-22, 2015.

[60] P. A. Kirschner and A. C. Karpinski, "Facebook® and academic performance," Comput. Human Behav., vol. 26, no. 6, pp. 1237$1245,2010$.

[61] J. Cassidy, "Me media," New Yorker 82, vol. no 13:50-9, 2006.

[62] M. Kalpidou, D. Costin, and J. Morris, "The Relationship Between Facebook and the Well-Being of Undergraduate College Students," Cyberpsychology, Behav. Soc. Netw., vol. 14, no. 4, pp. 183-189, 2011.

[63] Gemmill and Petterson, "Technology use among college students: Implications for student affairs professionals," NASPA J., vol. 43, no. 2, pp. 280-300, 2008.

[64] P. A. Kirschner and A. C. Karpinski, "Facebook and Academic Performance 1," Comput. Human Behav., vol. 26, no. 6, pp. 1237$1245,2010$.

[65] J. Pasek, E. More, and E. Hargittai, "The FG study," Peer-Reviewed J. Internet, vol. 14, no. 5, pp. 1-14, 2009.

[66] S. S. Jaggars and D. Xu, "How Do Online Course Design Features Influence Student Performance?," Comput. Educ., 2016.

[67] M. Al-Zoube, "E-Learning on the Cloud," Int. Arab J. e-technology, vol. 1, no. 2, pp. 58-64, 2009.

[68] J. McCarthy, "Utilising Facebook: immersing Generation-Y students into first year university," J. Educ. Res. Gr. Adelaide, vol. 1, no. 2, pp. 39-50, 2009.

[69] A. Simsek, "Interview with Tony Bates on the Aspects and Prospects of Online Learning," Contemp. Educ. Technol., vol. 2, no. 1, pp. 8894, 2011.

[70] H. N. Ali, P. B. Santoso, and M. A. Muslim, "Social Network Based Learning Management System," J. Comput. Eng., vol. 3, no. 2, pp. $18-23,2012$.

[71] L. Holcomb and M. Kruger-Ross, "Utilizing Web 2.0 Tools to Redesign and Support Communities of Practice in a Distance Education Course.pdf," in Society for Information Technology \& Teacher Education International Conference, 2012, pp. 406-411.

[72] P. C. Abrami, R. M. Bernard, E. M. Bures, E. Borokhovski, and R. M. Tamim, "Interaction in distance education and online learning: using evidence and theory to improve practice," J. Comput. High. Educ., vol. 23, no. 2-3, pp. 82-103, 2011.

[73] H. Azman, "Instrument Penilaian Pembimbing dalam Pelaksanaan Pembelajaran Berasaskan Kerja (PBK) Pelajar di Industri," Universiti Tun Hussien Onn, 2012.

[74] M. E. Sallabas, "Analysis of narrative texts in secondary school textbooks in terms of values education," African J. Bus. Educ., vol. 1, no. 3, pp. 59-63, 2013.

[75] J. W. Best and J. V Kahn, Research In Eduction. United State of America: A Viacom Company, 1998.

[76] A. M. Stewart, "Research Guide for A Students and Teachers," 2009

[77] R. Sharifah Nadiyah, S. Faaizah, H. Hanipah, and B. Norasiken, "Online collaborative learning elements to propose an online project based collaborative learning model," J. Teknol., vol. 77, no. 23, pp. 55-60, 2015.

[78] R. Sharifah Nadiyah, S. Faaizah, H. Hanipah, and B. Norasiken, "Factors That Affecting The Effective Online Collaborative Learning Environment," Pattern Anal. Intell. Secur. Internet Things, Adv. Intell. Syst. Comput. 355, pp. 293-302, 2014.

[79] R. Sharifah Nadiyah, S. Faaizah, and P. A. Gede, "A Proposed Model for Online Project Based Collaborative Learning: Expert Review,” J. Netw. Innov. Comput., vol. 3, pp. 1-6, 2015.

[80] R. Sharifah Nadiyah and S. Faaizah, "The Development of Online Project Based Collaborative Learning Using ADDIE Model," Procedia - Soc. Behav. Sci., vol. 195, pp. 1803-1812, 2015.

[81] R. K. Branson, G. T. Rayner, J. L. Cox, J. P. Furman, F. J. King, and W. H. Hannum, "Interservice procedures for instructional systems development: Executive summary and model," 1975.

[82] R. Watson, "Instructional System Development," in International Congress for Individualized Instruction, 1981.

[83] A. S. M. Lau, "Hospital-based nurses' perceptions of the adoption of Web 2.0 tools for knowledge sharing, learning, social interaction and the production of collective intelligence.," J. Med. Internet Res., vol. 13, no. 4, p. e92, Jan. 2011.

[84] H. M. Selim, "Critical success factors for e-learning acceptance: ConWrmatory factor models," Comput. Educ., vol. 49, pp. 396-413, 2007. 
[85] C. Lorenzo-Romero, M.-C. Alarcón-del-Amo, and E. Constantinides, "Determinants of Use of Social Media Tools in Retailing Sector," J. Theor. Appl. Electron. Commer. Res., vol. 9, no. 1, pp. 9-10, 2014.

[86] M. G. Moore, "Three types of interaction.," Am. J. Distance Educ., vol. 3, no. 2, pp. 1-6, 1989 .

[87] H. Ali, "A comparison of cooperative learning and traditional lecture methods in the project management department of a tertiary level institution in Trinidad and Tobago," Caribb. Teach. Sch., vol. 1, no. 1, pp. 49-64, 2011.

[88] C. L. Kimberlin and A. G. Winterstein, "Validity and reliability of measurement instruments used in research," Am J Heal. Syst Pharm, vol. 65 , no. 23, pp. 2276-84, 2008.

[89] N. M. Hanafi, A. A. Rahman, M. I. Mukhtar, J. Ahmad, and S. Warman, "Validity and Reliability of Competency Assessment Implementation ( CAI ) Instrument Using Rasch Model,” Int. J. Soc. Educ. Econ. Manag. Eng., vol. 8, no. 1, pp. 162-167, 2014

[90] A. Abdul Aziz, Rasch Model Fundamentals: Scale Construct and Measurement Structure. Kuala Lumpur: Integrated Advanced Planning Sdn.Bhd, 2010.

[91] T. M. Walser, "Quasi-Experiments in Schools: The Case for Historical Cohort Control Groups," Pract. Assessment, Res. Eval., vol. 19, no. 6, 2014.

[92] Y. Levy and T. J. Ellis, "A guide for novice researchers on experimental and quasi-experimental studies in information systems research," Interdiscip. J. Information, Knowledge, Manag., vol. 6, 2011.

[93] J. H. Lee, "Experimental methodology in English teaching and learning: Method features, validity issues, and embedded experimental design," English Teach., vol. 11, no. 2, pp. 25-43, 2012.

[94] B. M. Ngussa, "Application of ADDIE Model of Instruction in Teaching-Learning Transaction among Teachers of Mara Conference Adventist Secondary Schools, Tanzania,” J. Educ. Pract., vol. 5, no. 25 , pp. 1-11, 2014.
[95] Z. Gökkaya and N. Güner, "ADDIE Model in Adult Education Instructional Design Sample of E-Learning," in 5th International Future-Learning Conference on Innovations in Learning for the Future, 2014, vol. 53, no. 2011.

[96] L. Godzicki, N. Godzicki, M. Krofel, and R. Michaels, "Increasing Motivation and Engagement in Elementary and Middle School Students Through Technology-Supported Learning Environments," 2013.

[97] T. A. Bekele, "Motivation and satisfaction in internet-supported learning environments: A review," Educ. Technol. Soc., vol. 13, no. 2, pp. 116-127, 2010.

[98] B. Özmen and B. Atıc1, "The Effects of Social Networking Sites in Distance Learning on Learners' Academic Achievements," Eur. J. Open, Distance E-Learning, vol. 17, no. 2, Jan. 2014.

[99] J. Hewitt, "Toward an Understanding of How Threads Die in Asynchronous Computer Conferences," J. Learn. Sci., vol. 14, no. 4, pp. 567-589, 2005.

[100] N. Petrovica, V. Jeremica, M. Cirovica, Z. Radojicica, and N. Milenkovica, "Facebook Versus Moodle in Practice," Am. J. Distance Educ., vol. 28, no. 2, pp. 117-125, 2014.

[101] B. Thoms and E. Eryilmaz, "How media choice affects learner interactions in distance learning classes," Comput. Educ., vol. 75, pp. 112-126, 2014.

[102] D. Marijana, M. Aleksandar, B. Zorica, B. Dušan, and S. Krčo, "Providing Adaptivity in Moodle LMS Courses Adaptive e-learning systems," Educ. Technol. Soc., vol. 15, pp. 326-338, 2012.

[103] F.-F. Chua and C.-H. Choo, "Integrating social network services into virtual learning environment," Proc. - 2013 IEEE 13th Int. Conf. Adv. Learn. Technol. ICALT 2013, pp. 264-266, 2013.

[104] K. P. Brady, L. B. Holcomb, and B. V Smith, "The Use of Alternative Social Networking Sites in Higher Educational Settings : A Case Study of the E-Learning Benefits of Ning in Education," J. Interact. Online Learn., vol. 9, no. 2, pp. 151-170, 2010. 